\title{
Optimization of polysaccharides extracted from Verbena officinalis $L$ and their inhibitory effects on invasion and metastasis of colorectal cancer cells
}

\author{
Chao-chao Jin ${ }^{1}$, Xian-mei Liu ${ }^{2}$, Dan Ma ${ }^{1}$, Xian-liang Hua ${ }^{1}$ and Nuo $\mathrm{Jin}^{3 *}$ \\ ${ }^{1}$ Abdominal and Pelvic Medical Oncology II Ward (Minimally Invasive Department), ${ }^{2}$ Geriatrics Department, ${ }^{3}$ Sterilization and \\ Supply Department, Huangshi Central Hospital, Affiliated Hospital of Hubei Polytechnic University, E'dong Healthcare Group, \\ Huangshi 435000, PR China
}

*For correspondence: Email: jinnuogs@126.com; Tel/Fax: +86-0714-6256686

\begin{abstract}
Purpose: To investigate polysaccharides (PEV) extracted from the aerial part of Verbena officinalis $L$. and their inhibitory effects on the invasion and metastasis of colorectal cancer (CRC) cells. Methods: PEV was extracted by water and the optimization of extraction conditions was performed using a Box-Benhnken design (BBD). The cell viability was evaluated by 4,5-dimethylthiazol-2-yl)2,5diphenyltetrazolium bromide (MTT) assay. The effects of PEV on cell adhesion and invasion were evaluated by Transwell invasion, wound healing migration and adhesion assays in vitro. The effects of PEV on the expressions of matrix metalloproteinase-9 (MMP-9), mesenchymal-epithelial transition factor (C-met), E-cadherin (E-CAD), cyclooxygenase-2 (COX-2) and E-prostanoid 2 receptor (EP2) were investigated by western blot.

Results: The BBD model was established successfully for the optimization of PEV extraction $(p<$ 0.0001). The results indicate that PEV $(50,100$ and $200 \mu \mathrm{g} / \mathrm{mL})$ had significant inhibitory effects on cell invasion and migration of SW480 cells $(p<0.05)$. PEV also significantly decreased cell adhesion of SW480 cells. By treating with PEV, the expressions of C-met, MMP-9, COX-2 and EP2 were decreased, whereas the expression of E-CAD increased in SW480 cells.

Conclusion: RSM is effective for optimizing the extraction conditions of PEV. More importantly, PEV significantly inhibits the invasion and metastasis of SW480 cells by regulating the expression of MMP-9, $C$-met, E-CAD, COX-2 and EP2. Thus, PEV has the potential to be developed into therapeutic drugs for $C R C$ in the future.
\end{abstract}

Keywords: Polysaccharides, Colorectal cancer, Verbena officinalis, SW480 cell lines, Cell invasion, Metastasis

Tropical Journal of Pharmaceutical Research is indexed by Science Citation Index (SciSearch), Scopus, International Pharmaceutical Abstract, Chemical Abstracts, Embase, Index Copernicus, EBSCO, African Index Medicus, JournalSeek, Journal Citation Reports/Science Edition, Directory of Open Access Journals (DOAJ), African Journal Online, Bioline International, Open-J-Gate and Pharmacy Abstracts

\section{INTRODUCTION}

The incidence of colorectal cancer (CRC) is increasing and it has become the second most common cancer related deaths worldwide [1]. Although surgery, along with chemotherapy or radiotherapy, has been widely used for the treatment of CRC, the prognosis is still poor when the tumor has spread to lymph nodes or other organs [2,3]. A recent report from World Health Organization (WHO) revealed that the five-year survival rate for CRC patients (stage IV) is only $6 \%$ [4]. Therefore, finding agents to prevent the invasive progression of CRC would significantly benefit the patient outcomes. 
Verbena officinalis L., also called "mabiancao" in Chinese, is used as a medicinal herb in traditional Chinese medicine (TCM). The aerial part of this herb is commonly used in the southern part of the Yellow River of China for the treatment of bronchitis and rheumatism $[5,6]$. Modern pharmacological studies have shown that $V$. officinalis possessed various activities, such as anti-inflammatory, analgesic, immunity reinforcement, nerve protection and exciting uterine smooth muscle effects [6,7]. Researches on phytochemistry also have proved that $V$. officinalis contained many active constituents, including flavonoids, terpenoids, phenylpropanoids and iridoids [5]. However, there is no investigation on its polysaccharides and their pharmacological activities.

In the present study, the polysaccharides from $V$. officinalis and their inhibitory effects on invasion and metastasis of CRC cells were investigated, in order to determine their prospects in the treatment of CRC.

\section{EXPERIMENTAL}

\section{Chemicals and reagents}

RPMI 1640 culture medium was from Gibco BRL $\circledast$ (Grand Island, NY, USA). Fetal bovine serum (FBS) was purchased from HyClone ${ }^{\mathrm{TM}}$ (Logan, UT, USA). The primary antibodies against E-CAD, C-met, MMP-9, COX-2 and EP2 were obtained from Santa Cruz Biotechnology (Santa Cruz, CA, USA). Dimethylsulfoxide (DMSO) and MTT were purchased from Sigma (St. Louis, MO, USA).

\section{Plant material}

Aerial part of $V$. officinalis was purchased from an herbal market for Chinese medicine (Huangshi, China) in August 6, 2016, and identified by an expert in Traditional Chinese Medicine Department of Huangshi Central Hospital (Huangshi, China). A specimen (ST20150115) was stored at the laboratory of Huangshi Central Hospital (Huangshi, China).

\section{Extraction of PEV}

The dried powder $(50 \mathrm{~g})$ of the aerial part of $V$. officinalis was extracted by refluxing with distilled water. After extraction, the solutions were collected, filtered and concentrated to an appropriate volume under vacuum at $50^{\circ} \mathrm{C}$. The concentrated solutions were precipitated by adding anhydrous ethanol (final concentration of $80 \%, v / v)$ and left overnight $\left(4{ }^{\circ} \mathrm{C}\right)$. After centrifugation, the precipitates were collected and then washed anhydrous ethanol, benzene and acetone, respectively. The crude polysaccharides (PEV) were vacuum dried and the yield was calculated as in Eq 1.

Yield $(\%)=\left(\mathrm{P}_{0} / \mathrm{P}\right) 100$

where $P_{0}(g)$ is the weight of dried PEV; $P(g)$ is the weight of dried herbs.

\section{Optimization design}

A BBD with three independent factors (A, extraction time; $B$, number of extraction; $C$, water-solid ratio) at three levels coded with $-1,0$, 1 was used. The tested range of the three factors (A, B and C) and their levels are shown in Table 1.

Table 1: Factors and levels of BBD

\begin{tabular}{lccc}
\hline \multirow{2}{*}{ Factor } & \multicolumn{3}{c}{ Level } \\
\cline { 2 - 4 } & -1 & 0 & 1 \\
\hline Extraction time (A, min) & 60 & 90 & 120 \\
Number of extraction (B) & 1 & 2 & 3 \\
Water-solid ratio (C, & 10 & 20 & 30 \\
$\mathrm{~mL} / \mathrm{g})$ & &
\end{tabular}

\section{Cell culture}

CRC (SW480) cell line was from American Type Culture Collection (ATCC, Manassas, VA, USA). Cells were maintained in RPMI-1640 (the medium contained $10 \% \mathrm{FBS}$ ) at $37{ }^{\circ} \mathrm{C}$ with $5 \%$ $\mathrm{CO}_{2} / 95 \%$ air.

\section{Cell viability assay}

SW480 cells were plated into a 96 -well plate $(5 \mathrm{x}$ $10^{4} /$ well) and maintained overnight $\left(37^{\circ} \mathrm{C}\right)$. Then they were exposed to PEV (at concentrations of $50-600 \mu \mathrm{g} / \mathrm{mL}$ ), and then incubated for another $24 \mathrm{~h}$. Cell viability of SW480 cells was measured using the MTT method as previously reported [8].

\section{Cell invasion assay}

Matrigel-coated transwell chambers were used to evaluate the cell invasion of SW480 cells using the method described by Yuan et al [9]. The upper chambers were coated with matrigel (diluted in serum-free RPMI-1640 culture medium) and the bottom chambers were added RPMI-1640 medium (contained $10 \%$ FBS). SW480 cells $\left(5 \times 10^{4} / 200 \mu \mathrm{L}\right)$ were seeded onto the upper chambers. The cells were removed through the aperture $(8 \mu \mathrm{m})$ after $24 \mathrm{~h}$-incubation $\left(37^{\circ} \mathrm{C}\right)$. After staining with crystal violet (30 min), the migrated cells were observed using a microscope. 


\section{Wound-healing assay}

The method of wound-healing assay was reported by Huang et al [10]. SW480 cells were grown to confluence by incubating overnight. The wound was created manually by using the tip of a $200 \mu \mathrm{L}$-pipette. The cells were treated with PEV after washing with PBS for three times. After incubation for $24 \mathrm{~h}\left(37^{\circ} \mathrm{C}\right)$, the migration distance of the cells was observed under a microscope.

\section{Adhesion assay}

Cell adhesion assay was performed using the method reported previously with minor modifications [11]. Firstly, 96-well plates were pre-coated with fibronectin $(0.25 \mu \mathrm{g} /$ well $)$ overnight, and then blocked with $3 \%$ BSA. Cells $\left(5 \times 10^{5} / \mathrm{mL}\right)$ were suspended in $0.1 \% \mathrm{BSA}$, and seeded into each well coated with fibronectin. After incubation for $30 \mathrm{~min}$, each well was washed with PBS for three times. Attached cells were stained with crystal violet, and the absorbance was then measured at $590 \mathrm{~nm}$.

\section{Western blotting}

SW480 cells were cultured and pre-treated with of PEV for $48 \mathrm{~h}$. The lysates of SW480 cells were prepared and then centrifuged $(12,000 \times \mathrm{g}, 4$ $\left.{ }^{\circ} \mathrm{C}\right)$. The obtained proteins $(50 \mu \mathrm{\mu g})$ were separated on $10 \%$ sodium dodecyl sulfate (SDS)/polyacrylamide gel electrophoresis (PAGE), and then electrophoretically transferred to polyvinylidene Fluoride (PVDF) membranes. After blocking (5\% skimmed milk) and incubating with the specific antibodies overnight $\left(4^{\circ} \mathrm{C}\right)$, the membranes were then incubated with HRPconjugated secondary antibodies (2 h) and blots were visualized using enhanced chemiluminescence.

\section{Statistical analysis}

The data analysis of RSM experiments was performed with Design-Expert software (version V8.0.6) (Stat-Ease, Inc., Minneapolis, MN, USA) and one-way analysis of variance (ANOVA) was used to analyze the statistical significance. Statistical analysis was determined by performing the Student's $t$ test, and $p<0.05$ was considered statistically different.

\section{RESULTS}

\section{Optimized data}

The complete design matrix and PEV yield (response values) obtained are shown in Table 2. Multiple regression analysis was used to analyze the experiment data of BBD. The response value $(Y)$ and the tested factors $(A, B$ and $\mathrm{C}$ ) are related by $\mathrm{Eq} 2$, according to the coded values. $Y=+1.44+0.005 A+0.046 B+0.091 C+$
$0.042 A B-0.0025 A C-0.030 B C-0.052 A^{2}-$
$\left.0.16 B^{2}-0.059 C^{2} \ldots \ldots \ldots \ldots . .12\right)$

From the analysis (Table 3 ), the low model $p$ value $(<0.0001)$, indicates that the established RSM was highly significant. The high $\mathrm{R}^{2}(0.9947)$ and $\operatorname{adj}-R^{2}(0.9880)$ showed goodness-of-fit between the data from actual experiments and the data predicted by the established model. The value of the coefficient of variation (CV) (1.02) indicated low deviations between actual experimental data and predicted data.

Table 2: BBD design and the obtained PEV yield

\begin{tabular}{|c|c|c|c|c|}
\hline Run & A & B & C & Yield (\%) \\
\hline 1 & 0.00 & 0.00 & 0.00 & 1.45 \\
\hline 2 & 1.00 & 0.00 & -1.00 & 1.25 \\
\hline 3 & -1.00 & 0.00 & 1.00 & 1.41 \\
\hline 4 & 0.00 & -1.00 & 1.00 & 1.29 \\
\hline 5 & 0.00 & 0.00 & 0.00 & 1.44 \\
\hline 6 & 0.00 & 1.00 & -1.00 & 1.21 \\
\hline 7 & 0.00 & -1.00 & -1.00 & 1.05 \\
\hline 8 & 0.00 & 1.00 & 1.00 & 1.33 \\
\hline 9 & 0.00 & 0.00 & 0.00 & 1.42 \\
\hline 10 & 0.00 & 0.00 & 0.00 & 1.45 \\
\hline 11 & 1.00 & 1.00 & 0.00 & 1.31 \\
\hline 12 & 1.00 & -1.00 & 0.00 & 1.14 \\
\hline 13 & -1.00 & -1.00 & 0.00 & 1.23 \\
\hline 14 & -1.00 & 0.00 & -1.00 & 1.22 \\
\hline 15 & 1.00 & 0.00 & 1.00 & 1.43 \\
\hline 16 & -1.00 & 1.00 & 0.00 & 1.23 \\
\hline 17 & 0.00 & 0.00 & 0.00 & 1.43 \\
\hline
\end{tabular}


The high degree of adequate precision (37.538) also showed good reliability of the established model. ANOVA results also indicated that the coefficients of $B, C, A^{2}, B^{2}, C^{2}, A B$ and $B C$ exhibited significant effects on the yield of PEV $(p<0.01)$, while the other coefficients of $A$ and AC were found nonsignificant $(p>0.05)$. The results also demonstrated that the number of extraction (B) and the water-solid ratio $(\mathrm{C})$ were significantly associated with the PEV yield.

\section{Response surface analysis and verification of the model}

Through contour plots and response surface plots (Figure 1), the relationship between the tested factors and PEV yield were evaluated. The optimum conditions for maximum PEV yield were obtained: extraction time of $91.98 \mathrm{~min}$, number of extractions of 2.08, and solid-water ratio of $27.50 \mathrm{~g} / \mathrm{mL}$.
The adequacy of the BBD model was validated by performing a verification experiment under the modified optimum conditions (extraction time of 92 min, number of extractions of 2, and solidwater ratio of $27.50 \mathrm{~g} / \mathrm{mL}$ ). As a result, the obtained yield $(1.48 \pm 0.06 \%)$ of PEV under these conditions $(n=3)$ was well-matched with the predicted value from the model $(1.47 \%)$.

\section{Effects of PEV SW480 cell viability}

Cell viability was evaluated by MTT to select a suitable PEV concentration for investigating the cell invasion and metastasis of SW480 cells. As shown in Figure 2, PEV inhibited the growth of SW480 cells at high concentrations (> 400 $\mu \mathrm{g} / \mathrm{mL}$ ). However, PEV showed no obviously inhibitory effect on the growth of SW480 cells at concentrations ranged from 50 to $300 \mu \mathrm{g} / \mathrm{mL}$. Therefore, PEV of 50, 100 and $200 \mu \mathrm{g} / \mathrm{mL}$ were selected for further study.

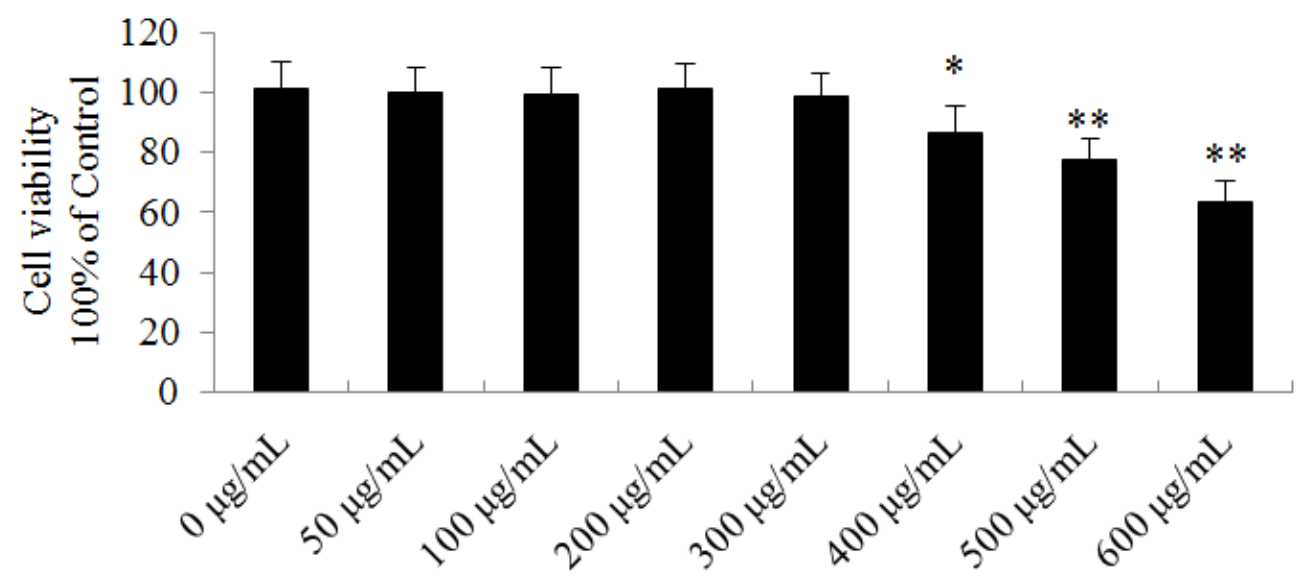

Figure 2: Effects of PEV on viability of SW480 cells. ${ }^{*} p<0.05$ vs. control group; ${ }^{*} p<0.01$ vs. control group

Table 3: ANOVA for RSM of PEV extraction

\begin{tabular}{|c|c|c|c|c|c|c|c|}
\hline Variables & & Sum of squares & df & Mean square & & $F$-value & $P$-value \\
\hline Model & & 0.24 & 9 & 0.026 & & 147.20 & $<0.0001$ \\
\hline$A$ & & 2.00E-4 & 1 & $2.00 \mathrm{E}-4$ & & 1.12 & 0.3260 \\
\hline B & & 0.017 & 1 & 0.017 & & 95.45 & $<0.0001$ \\
\hline C & & 0.067 & 1 & 0.067 & & 371.54 & $<0.0001$ \\
\hline$A \times B$ & & 7.23E-3 & 1 & $7.23 E-3$ & & 40.30 & 0.0004 \\
\hline$A \times C$ & & $2.50 E-5$ & 1 & $2.50 \mathrm{E}-5$ & & 0.14 & 0.7199 \\
\hline$B \times C$ & & $3.60 \mathrm{E}-3$ & 1 & $3.60 \mathrm{E}-3$ & & 20.08 & 0.0029 \\
\hline$A^{2}$ & & 0.011 & 1 & 0.011 & & 62.29 & $<0.0001$ \\
\hline $\mathrm{B}^{2}$ & & 0.11 & 1 & 0.11 & & 593.72 & $<0.0001$ \\
\hline$C^{2}$ & & 0.015 & 1 & 0.015 & & 81.75 & $<0.0001$ \\
\hline Residual & & $1.26 \mathrm{E}-3$ & 7 & $1.79 \mathrm{E}-4$ & & & \\
\hline Lack of Fit & & $5.75 E-4$ & 3 & $1.92 \mathrm{E}-4$ & & 1.13 & 0.4378 \\
\hline Pure Error & & $6.80 \mathrm{E}-4$ & 4 & $1.70 \mathrm{E}-4$ & & & \\
\hline Cor Total & & 0.24 & 16 & & & & \\
\hline $\begin{array}{l}\text { Standard } \\
\text { Deviation }\end{array}$ & Mean & $\mathrm{R}^{2}$ & $R^{2}$ Adj & $\mathrm{R}^{2}$ Pred & C.V.\% & Press & $\begin{array}{l}\text { Adequate } \\
\text { precision }\end{array}$ \\
\hline 0.013 & 1.31 & 0.9947 & 0.9880 & 0.9570 & 1.02 & 0.010 & 37.538 \\
\hline
\end{tabular}



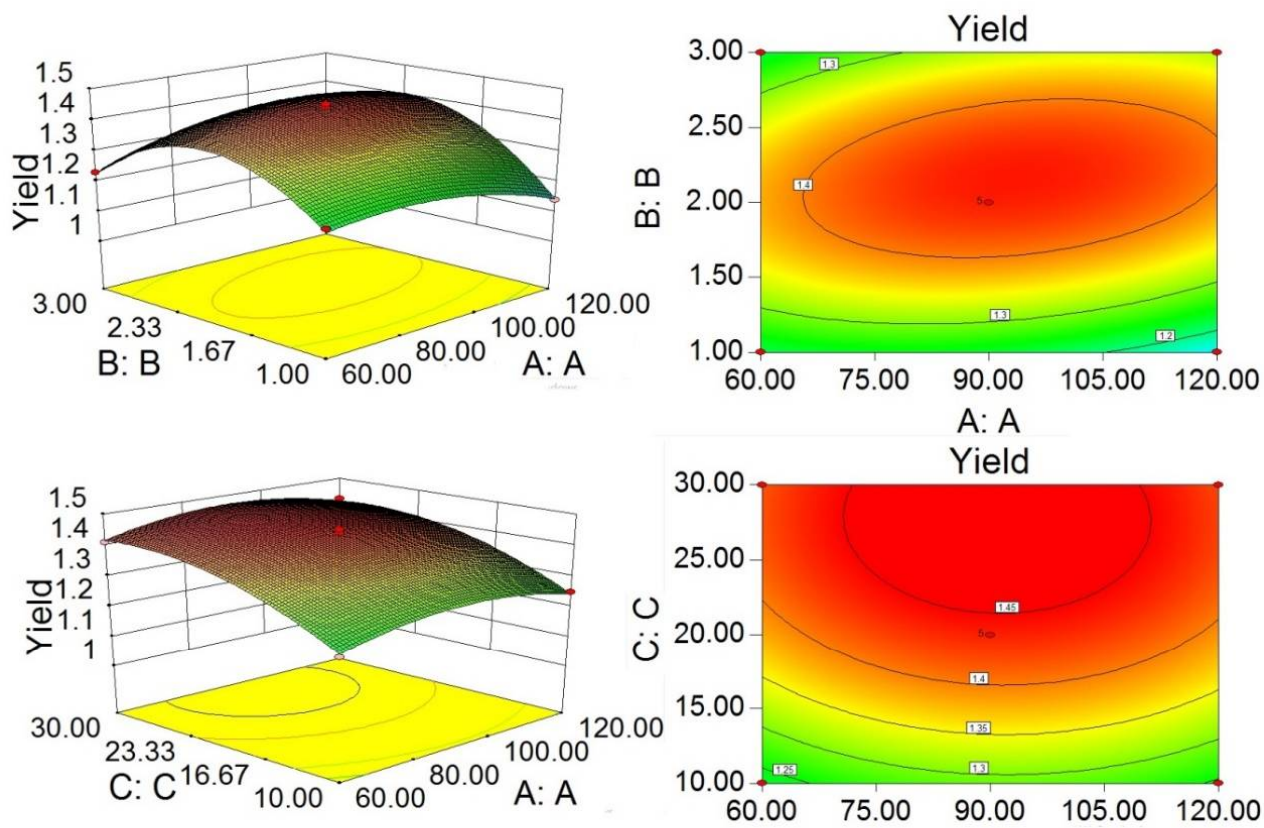

A: A
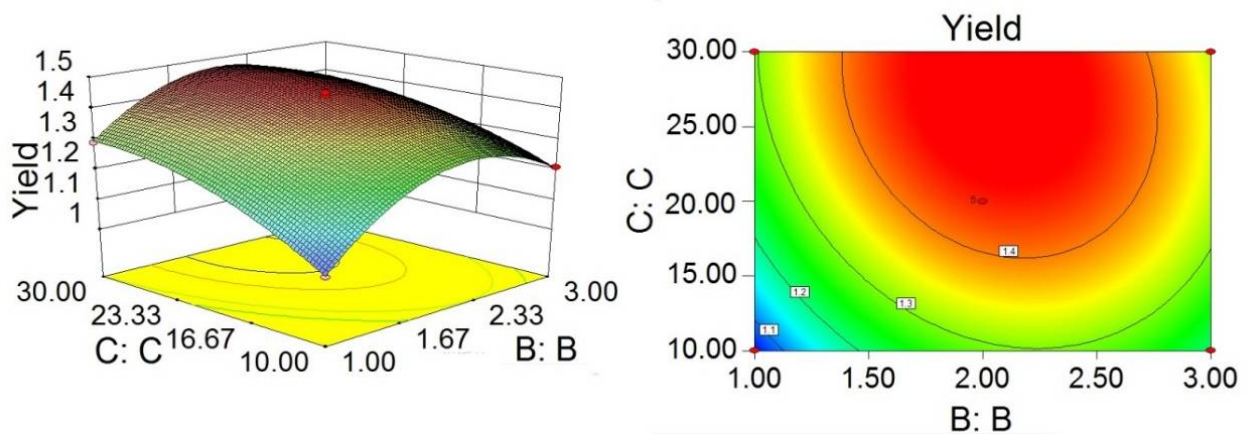

Figure 1: 3-dimensional response surface plots and 2-dimensional contour plots showing effects of the factors on PEV yield

\section{In vitro invasion, wound healing and adhesion}

PEV effectively inhibited the invasion of SW480 cells at concentrations of 50,100 and $200 \mu \mathrm{g} / \mathrm{mL}$ ( $p<0.05, p<0.01$ and $p<0.01$, respectively) (Figure 3A). Wound healing assay indicated that the healing rates of PEV-treated cells were reduced with a concentration-dependent manner (Figure 3b). Furthermore, PEV also inhibited the adhesion of SW480 cells to fibronectin, and achieved the highest reduction (approximately 60 $\%$ ) at $200 \mu \mathrm{g} / \mathrm{mL}$ (Figure 3C).

\section{Effects of PEV on expressions of E-CAD, C- met, MMP-9, COX-2 and EP2}

As shown in Figure 4, the results indicated that treatment of PEV $(100$ and $200 \mu \mathrm{g} / \mathrm{mL})$ significantly increased the expression of E-CAD, and decreased the expressions of C-met and MMP-9. Furthermore, the expressions of COX-2 and EP2 were significantly down-regulated in
SW480 cells by treating with PEV (100 and 200 $\mu \mathrm{g} / \mathrm{mL})$.

\section{DISCUSSION}

Response surface methodology (RSM) is reported to be an effective method widely used for optimizing parameters of extraction in food and pharmaceutical research [12]. As one type of RSM, BBD is popularly used to optimize the parameters in extration process [13]. Compared with conventional methods, BBD can save materials, decrease expenses and reduce time, etc. in optimizing a process [14]. In this study, the conditions for PEV extraction were optimized by using a BBD, and the optimum conditions for PEV extraction were obtained: extraction time of 92 min, number of extractions of 2 , and solidwater ratio of $27.50 \mathrm{~g} / \mathrm{mL}$.

MMPs are reported to be the pivotal extracellular matrix (ECM) degradation enzymes required for the invasion and metastasis of tumor cells. 

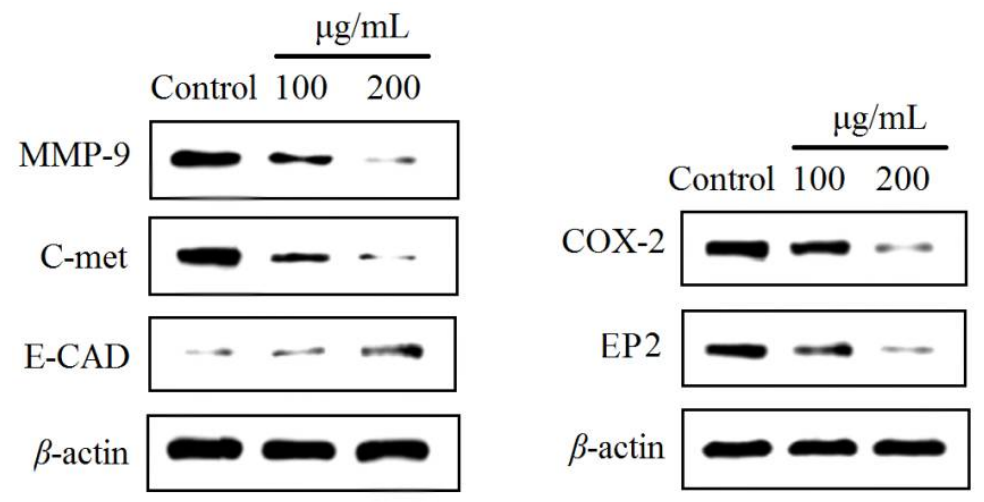

Figure 4: Effects of PEV on the expressions of E-CAD, C-met, MMP-9, COX-2 and EP2

A

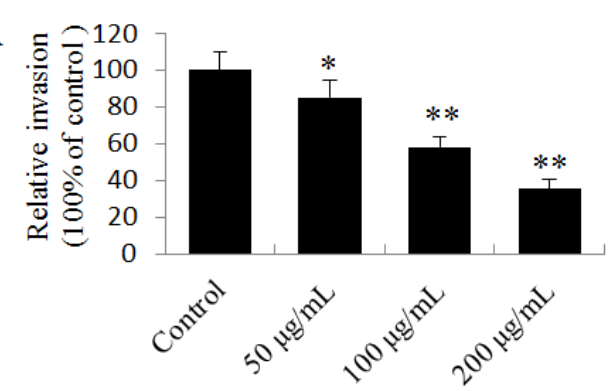

B

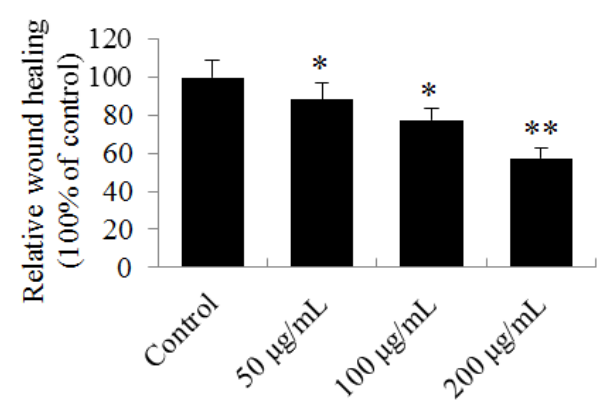

C

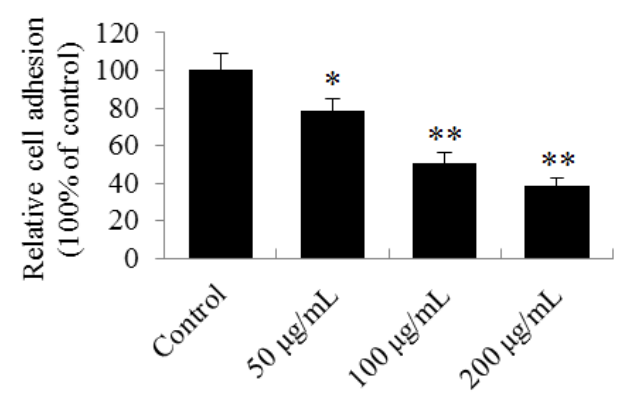

Figure 3: In vitro effects of PEV on invasion (A), wound healing $(B)$ and adhesion $(C)$ of SW480 cells; ${ }^{*} p<0.05$ vs. the control group; ${ }^{*} p<0.01$ vs. control group

As one of the MMPs, MMP-9 is closely associated with metastasis of most cancers including CRC [15]. The function, activity and expression intensity of E-cadherin (E-CAD) play crucial roles in the separation and reattachment of tumor cells [16]. C-met, belongs to the receptor tyrosine kinase (RTK) family, is found to be abnormal in many types of tumors. Expression of C-met has been proved to be an important signaling pathway which is responsible for proliferation, invasion, migration, and metastasis, etc. of tumor cells [17]. In this study, the effects of PEV on the expressions of MMP-9, $\mathrm{E}-\mathrm{CAD}$ and $\mathrm{C}$-met proteins were measured by using western blot, and the results demonstrated that PEV significantly increased the expression of E-CAD protein and decreased the expression of C-met and MMP-9 proteins.

Over-expression of COX-2 was found to be closely associated with colorectal tumorigenesis, and it can enhance the angiogenesis, attachment and migration/invasion of tumor cells [18]. In addition, prostaglandin $E_{2}\left(P E G_{2}\right)$ is the main catalyzed product of $\mathrm{COX}-2$ from arachidonic acid, and $\mathrm{PGE}_{2}$ produces its cellular signaling via activating G-protein coupled receptors (GCPRs). EP2 is one of the GCPRs which played vital roles in CRC $[19,20]$. In this study, the effects of PEV treatment on COX-2 and EP2 expressions were also determined, and found that they were significantly down-regulated by treating with PEV.

\section{CONCLUSION}

RSM is an effective method for optimizing the extraction conditions of PEV. Furthermore, PEV significantly inhibits the invasion and metastasis of SW480 cells. The mechanisms operates probably via the regulation of the expression of MMP-9, C-met, E-CAD, COX-2 and EP2. Consequently, PEV can potentially be developed into therapeutic drugs for colorectal cancer.

\section{DECLARATIONS}

\section{Acknowledgement}

None.

\section{Conflict of Interest}

No conflict of interest associated with this work. 


\section{Contribution of Authors}

The authors declare that this work was done by the authors named in this article and all liabilities pertaining to claims relating to the content of this article will be borne by them.

\section{Open Access}

This is an Open Access article that uses a funding model which does not charge readers or their institutions for access and distributed under the terms of the Creative Commons Attribution License (http://creativecommons.org/licenses/by/ 4.0) and the Budapest Open Access Initiative (http://www.budapestopenaccessinitiative.org/rea d), which permit unrestricted use, distribution, and reproduction in any medium, provided the original work is properly credited.

\section{REFERENCES}

1. Liu LY, Huang WJ, Ho FM, Lin RJ, Lin SY, Suk FM, Liang YC. N-Hydroxycinnamide derivatives of osthole inhibit cell migration and invasion by suppressing Smad2 and Akt pathways in human colorectal adenocarcinoma cells. Chem Biol Interact 2014; 217: 1-8.

2. Sathyanarayanan A, Chandrasekaran KS, Karunagaran D. microRNA-146a inhibits proliferation, migration and invasion of human cervical and colorectal cancer cells. Biochem Biophys Res Commun 2016; 480(4): 528-533.

3. Pooja T, Karunagaran D. Emodin suppresses Wnt signaling in human colorectal cancer cells SW480 and SW620. Eur J Pharmacol. 2014; 742: 55-64.

4. Jiang $H$, Wu L, Chen J, Mishra M, Chawsheen HA, Zhu $H$, Wei Q. Sulfiredoxin Promotes Colorectal Cancer Cell Invasion and Metastasis through a Novel Mechanism of Enhancing EGFR Signaling. Mol Cancer Res. 2015; 13(12): 1554-1566.

5. Shu J, Chou G, Wang Z. Two new iridoids from Verbena officinalis L. Molecules. 2014; 19(7):10473-10479.

6. Liu Z, Xu Z, Zhou H, Cao G, Cong XD, Zhang Y, Cai BC. Simultaneous determination of four bioactive compounds in Verbena officinalis L. by using highperformance liquid chromatography. Pharmacogn Mag 2012; 8(30): 162-165.

7. Lai SW, Yu MS, Yuen WH, Chang R. Novel neuroprotective effects of the aqueous extracts from Verbena officinalis L. Neoro Pharmacol 2006; 50(6):641650.

8. Chidambara Murthy KN, Jayaprakasha GK, Patil BS. Dlimonene rich volatile oil from blood oranges inhibits angiogenesis, metastasis and cell death in human colon cancer cells. Life Sci 2012; 91(11-12): 429-439.

9. Yuan $S$, Wang $L$, Chen $X$, Fan $B$, Yuan $Q$, Zhang $H$, Yang $D$, Wang $S$. Triptolide inhibits the migration and invasion of human prostate cancer cells via Caveolin-
1/CD147/MMPs pathway. Biomed Pharmacother 2016; 84: 1776-1782.

10. Huang $M, W u S$, Hu Q, Wu H, Wei S, Xie H, Sun K, Li X, Fang L. Agkihpin, a novel SVAE may inhibit the migration and invasion of liver cancer cells associated with the inversion of EMT induced by Wnt/B-catenin signaling inhibition. Biochem Biophys Res Commun 2016; 479(2): 283-289.

11. Sato T, Takahashi M, Kawado T, Takayama E, Furukawa $K$. Effect of staurosporine on $\mathrm{N}$-glycosylation and cell adhesion to fibronectin of SW480 human colorectal adenocarcinoma cells. Eur J Pharm Sci; 25(2-3): 221227.

12. Ji YB, Dong F, Ma DB, Miao J, Jin LN, Liu ZF, Zhang LW. Optimizing the extraction of anti-tumor polysaccharides from the fruit of Capparis spionosa L. by response surface methodology. Molecules 2012; 17(6):73237335.

13. Liu M1, Jing H, Zhang J, Che G, Zhou M, Gao Z2, Li S, Ren Z, Hao L, Liu Y, Jia L. Optimization of Mycelia Selenium Polysaccharide Extraction from Agrocybe cylindracea SL-02 and Assessment of their Antioxidant and Anti-Ageing Activities. PLoS One 2016; 11(8): e0160799.

14. Pu JB, Xia BH, Hu YJ, Zhang HJ, Chen J, Zhou J, Liang WQ, XU P. Multi-Optimization of Ultrasonic-Assisted Enzymatic Extraction of Atratylodes macrocephala Polysaccharides and Antioxidants Using Response Surface Methodology and Desirability Function Approach. Molecules 2015; 20(12): 22220-22235.

15. Chiu KY, Wu CC, Chia CH, Hsu SL, Tzeng YM. Inhibition of growth, migration and invasion of human bladder cancer cells by antrocin, a sesquiterpene lactone isolated from Antrodia cinnamomea, and its molecular mechanisms. Cancer Lett 2016; 373(2): 174-184.

16. Kandouz M, Alachkar A, Zhang L, Dekhil H, Chehna F, Yasmeen A, Al Moustafa AE. Teucrium polium plant extract inhibits cell invasion and motility of human prostate cancer cells via the restoration of the Ecadherin/catenin complex. J Ethnopharmacol. 2010; 129(3):410-415.

17. Park $B H$, Jung $K H$, Yun SM, Hong SW, Ryu JW, Jung $H$, Ha JD, Lee J, Hong SS. KRC-327, a selective novel inhibitor of c-Met receptor tyrosine kinase with anticancer activity. Cancer Lett 2013; 331(2):158-166.

18. Liu X, Ji Q, Ye N1, Sui H, Zhou L, Zhu H, Fan Z, Cai J, Li $Q$. Berberine Inhibits Invasion and Metastasis of Colorectal Cancer Cells via COX-2/PGE2 Mediated JAK2/STAT3 Signaling Pathway. PLoS One 2015; 10(5): e0123478.

19. Zheng H, Li Y, Wang Y, Zhao H, Zhang J, Chai H, Tang $T$, Yue J, Guo AM, Yang J. Downregulation of COX-2 and CYP $4 A$ signaling by isoliquiritigenin inhibits human breast cancer metastasis through preventing anoikis resistance, migration and invasion. Toxicol Appl Pharmacol 2014; 280(1): 10-20.

20. Fujino $H$, Chen XB, Regan JW, Murayama $T$. Indomethacin decreases EP2 prostanoid receptor

Trop J Pharm Res, October 2017; 16(10): 2393 
